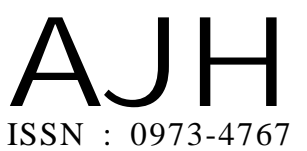

Article history :

Received : 25.10.2019

Revised : 04.11.2019

Accepted : 18.11.2019
RESEARCH PAPER

DOI : 10.15740/HAS/TAJH/14.2/17-22

\section{Evaluation of ridge gourd (Luffa acutangula Roxb) hybrids during summer season for growth, yield and quality traits}

\author{
V. Krishnamoorthy
}

ABSTRACT : The study was conducted at Department of Horticulture, Agricultural College and Research Institute, Madurai. The hybridization programme was carried out during Kharif 2017 and 24 hybrids were evolved through Line x Tester mating design. Six inbreed lines (L) were used as female parents viz. $\mathrm{L}_{1}$ was PKM-1(High yield), $\mathrm{L}_{2}$ was CO-1 (High yield), $\mathrm{L}_{3}$ was Virdhunagar Local (Earliness), $\mathrm{L}_{4}$ was Seranmadevi local (More number of fruits/plant), $\mathrm{L}_{5}$ was Arka Sujath (High yield), $\mathrm{L}_{6}$ was Arka Sumeet (High yield) and four inbreds as male parents were tester ( $\mathrm{T}$ ), $\mathrm{T}_{1}$ was Periyakottai local ( High length of fruits), $\mathrm{T}_{2}$ was Alathur local (Fruit diameter), $\mathrm{T}_{3}$ was Kannapatti Local (Node to first female flower appear), $\mathrm{T}_{4}$ was Srirampuram Local (More Female: Male ratio). The twenty four hybrids were evaluated during 2018 summer season to identify superior hybrids suitable commercial cultivation during summer season. The performance of parents and hybrids showed that the parents $\mathrm{T}_{1}(1.02 \mathrm{~kg} / \mathrm{vine})$ and $\mathrm{T}_{2}(1.01 \mathrm{~kg} /$ vine) were high yielding. Among the twenty four crosses, three cross combinations viz., $\mathrm{L}_{3} \times \mathrm{T}_{2}$ (1.35kg/vine), $\mathrm{L}_{3} \times \mathrm{T}_{1}(0.96 \mathrm{~kg} / \mathrm{vine}), \mathrm{L}_{4} \times \mathrm{T}_{1}(0.93 \mathrm{~kg} / \mathrm{vine})$ recorded highest yield per vine. The high fruit weight was recorded in $\mathrm{L}_{3} \times \mathrm{T}_{1}(315 \mathrm{~g}), \mathrm{L}_{4} \mathrm{xT}(270 \mathrm{~g}), \mathrm{L}_{4} \mathrm{xT} \mathrm{T}_{4}(250 \mathrm{~g})$. The highest number of fruits per vine was recorded in $\mathrm{L}_{3} \mathrm{xT}_{2}(4.27), \mathrm{L}_{3} \mathrm{xT}$ ( 4 .25) and $\mathrm{L}_{3} \mathrm{xT}$ (4.05). The yield per hectare was high in $\mathrm{L}_{3} \mathrm{xT} \mathrm{T}_{1}(5.38 \mathrm{t}), \mathrm{L}_{3} \mathrm{xT} \mathrm{T}_{2}(3.82 \mathrm{t})$ and $\mathrm{L}_{4} \mathrm{xT} \mathrm{T}_{1}(3.74 \mathrm{t})$. The high total soluble solids was observed in $\mathrm{L}_{6} \mathrm{xT}_{2}\left(6.0^{\circ} \mathrm{Brix}\right)$ and $\mathrm{L}_{1} \times \mathrm{T}_{3}\left(5.0^{\circ} \mathrm{Brix}\right)$ hybrids. The highest crude fibre content was estimated in $\mathrm{L}_{4} \mathrm{xT}_{4}(0.59 \mathrm{mg} / 100 \mathrm{~g}), \mathrm{L}_{3} \mathrm{xT}_{2}(0.58 \mathrm{mg} / 100 \mathrm{~g})$ and $\mathrm{L}_{4} \mathrm{xT}_{3}(0.57 \mathrm{mg})$ hybrids.

KEY WORDS : Ridge gourd, Summer season, Growth, Yield, Quality traits

HOW TO CITE THIS ARTICLE : Krishnamoorthy, V. (2019). Evaluation of ridge gourd (Luffa acutangula Roxb) hybrids during summer season for growth, yield and quality traits. Asian J. Hort., 14(2) : 17-22, DOI : 10.15740/HAS/TAJH/14.2/17-22. Copyright@2019 : Hind Agri -Horticultural Society 